\section{A. ARS BILDUMA ISSN 1989-9262
UPV/EHU Press} ARSBILDUMA (CC BY-NC-ND 4.0)

https://doi.org/10.1387/ars-bilduma.22268 BIBLID [(2021), 11; 157-169]

Recibido: 01/07/2020 Aceptado: 20/11/2020

\section{JUAN CARLOS APARICIO VEGA}

Universidad de Oviedo

Departamento de Historia del Arte y Musicología Facultad de Filosofía y Letras

C/Amparo Pedregal, s/n

33011 Oviedo (Asturias)

apariciojuan@uniovi.es

https://orcid.org/0000-0002-0338-3743

\title{
LA EXPOSICIÓN DEL ARCA SANTA DE LA CATEDRAL DE OVIEDO EN EL MUSEO DEL PRADO (1935)
}

THE EXHIBITION OF THE HOLY ARK BELONGING TO THE OVIEDO CATHEDRAL IN THE PRADO MUSEUM (1935)

\section{L'EXPOSITION DE L'ARCHE SAINTE DE LA CATHÉDRALE D'OVIEDO AU MUSÉE DU PRADO (1935)}

RESUMEN

Resumen: En 1935 el público del Museo del Prado pudo contemplar por vez primera fuera de su marco habitual, el Arca Santa (c. 1096-1101) de la Catedral de Oviedo, uno de los relicarios más singulares del románico europeo y pieza esencial de la Cámara Santa. Esta presentación estuvo relacionada con su restauración en el Instituto Valencia de Don Juan. En la dilatada historiografía sobre esta obra maestra, apenas se registr dicha exhibición, que ahora relatamos en base a documentos inéditos.

\section{PALABRAS CLAVE}

Museo del Prado; Oviedo; Arca Santa; Cámara Santa; Revolución de Octubre; Exposición; Instituto Valencia de don Juan; Museo Arqueológico Nacional.

\section{ABSTRACT}

In 1935 the Prado Museum's audience had the opportunity to admire the Holy Ark (c. 1096-1101) belonging to the Oviedo Cathedral, one of the most unique reliquaries of European Romanesque and an essential piece of the Holy Chamber, outside its usual setting for the first time. This display was connected to its restoration at the Instituto Valencia de Don Juan. The extensive historiography on thi masterpiece barely contains any entries about this exhibition, which we now narrate it here, based on unpublished documents.

KEYWORDS

Prado Museum; Oviedo; Holy Ark; Holy Chamber; Spanish October Revolution Exhibition; Instituto Valencia de Don Juan National Archaeological Museum of Spain.
RÉSUMÉ

En 1935, le public du Musée du Prado put admirer, pour la première fois hors de son cadre habituel, l'Arche Sainte (c. 1096-1101) de la Cathédrale d'Oviedo, l'un des reliquaires les plus uniques de l'art roman européen et une pièce essentielle de la Sainte Chambre. Cette présentation fut liée à sa restauration chez l'Instituto Valencia de Don Juan. Dans l'abbondante historiographie sur ce chef-d'œuvre cette exposition non est presque pas notée. Nous la décrivons maintenant sur la base de documents inédits.

\section{MOTS-CLÉS}

Musée du Prado; Oviedo; Arche Sainte; Sainte Chambre; Révolution d'Octobre Espagnole; exposition; Instituto Valencia de Don Juan; Musée National d'Archéologie d'Espagne. 


\section{INTRODUCCIÓN}

El Arca Santa de la Catedral de Oviedo permanece desde hace cerca de un milenio asociado al célebre relicario altomedieval conocido con el nombre de Cámara Santa (s. IX) (Figs. 1-2), acomodado a la zona sur del complejo conjunto arquitectónico actual del templo ${ }^{1}$. Su misma cronología, desconocida, y hasta su historia primera sigue siendo objeto de revisiones académicas en la actualidad. Ligada muy probablemente al proceso historiográfico emprendido por el obispo Don Pelayo (1101-1130) en la sede ovetense ${ }^{2}$, la pieza podría haberse ejecutado entre la fecha marcada por la apertura del relicario ovetense el 13 de marzo de 1075 a cargo del monarca Alfonso VI y el final de su reinado el año $1109^{3}$.

Durante siglos, no consta ningún traslado de la pieza fuera de los muros de la Catedral de Oviedo y, sin embargo, sería a lo largo de unos pocos años de la pasada centuria cuando se concentrasen los mayores movimientos de la misma. De este modo, el Arca de las reliquias ovetense acompañó a otras preciadas piezas esenciales del tesoro catedralicio para se expuestas en la Exposición Internacional de Barcelona celebrada en el Palacio Naciona

*Agradezco las atenciones e informaciones facilitadas por Yolanda Cardito Rollán (Archivo del Museo Artes de San Fernando pano (Museo Nacional de Fscultura, Valladolid), Aurora Ladero Galán (Archivo del Museo Arqueológico Nacional, Madrid), Ana Herrero Montero (Archivo Municipal de Oviedo), Pilar Plaza Torrijo (Biblioteca de la Universidad de Oviedo), Paula Lafuente Gil (Registro del Museo de Bellas Artes de Asturias, Oviedo), Teresa Caballero Navas (Biblioteca del Museo de Bellas Artes de Asturias, Oviedo) Juan Miguel Menéndez Llana (Biblioteca de Asturias Ramón Pérez de Ayala, Oviedo) y Ana María Quijada Espina (Servicio de Patrimonio de la Universidad de Oviedo).

En el Instituto Valencia de Don Juan, una vez consultado, no se conserva huella documental ni gráfica alguna del paso del Arca Santa y el resto de piezas de la Catedral de Oviedo por más de medio año.

2 ALONSO ÁLVAREZ, R. «Patria uallata asperitate moncium»: Pelayo de Oviedo, el "archa" de las reliquias y la creación de una topografía regia», Locus Amoenus, n 9, 2007-2008, pp. 17-29.

La última revisión de esta cuestión ha sido realizada por el arqueólogo García de Castro. Este investigador incluso apura la fecha límite hasta el 1101 actual, basándose en la fecha de muerte de la infant Urraca. Apunta además el autor las visitas del monarca a Oviedo los años 1096 y 1097 como los de probable encargo y entrega del relicario. Consúltese: GARCÍA DE CASTRO VALDÉS, C.: El Arca Santa de la Catedral de Oviedo. Aguilar de Campoo, Fundación Santa María la Real del Patrimonio Histórico 2017 pp 82-84 Asimismo, son de releyancia los artículos referidos al relicario ovetense inchidos FERNÁNDEZ CONDE, F. J. Y ALONSO ÁLVAREZ, R. (eds): Ias reliquias de la catedal de Oviedo: Panorama general desde una perspectiva crítica (I)», Territorio Sociedad y Poder, n ${ }^{\circ} 11,2017$; FERNÁNDEZ CONDE, F. J. y ALONSO ÁLVAREZ, R. (eds.): «Las reliquias de la catedral de Oviedo: Panorama general desde una perspectiva crítica (II)», Territorio Sociedad y Poder, $\mathrm{n}^{\circ} 12,2018$

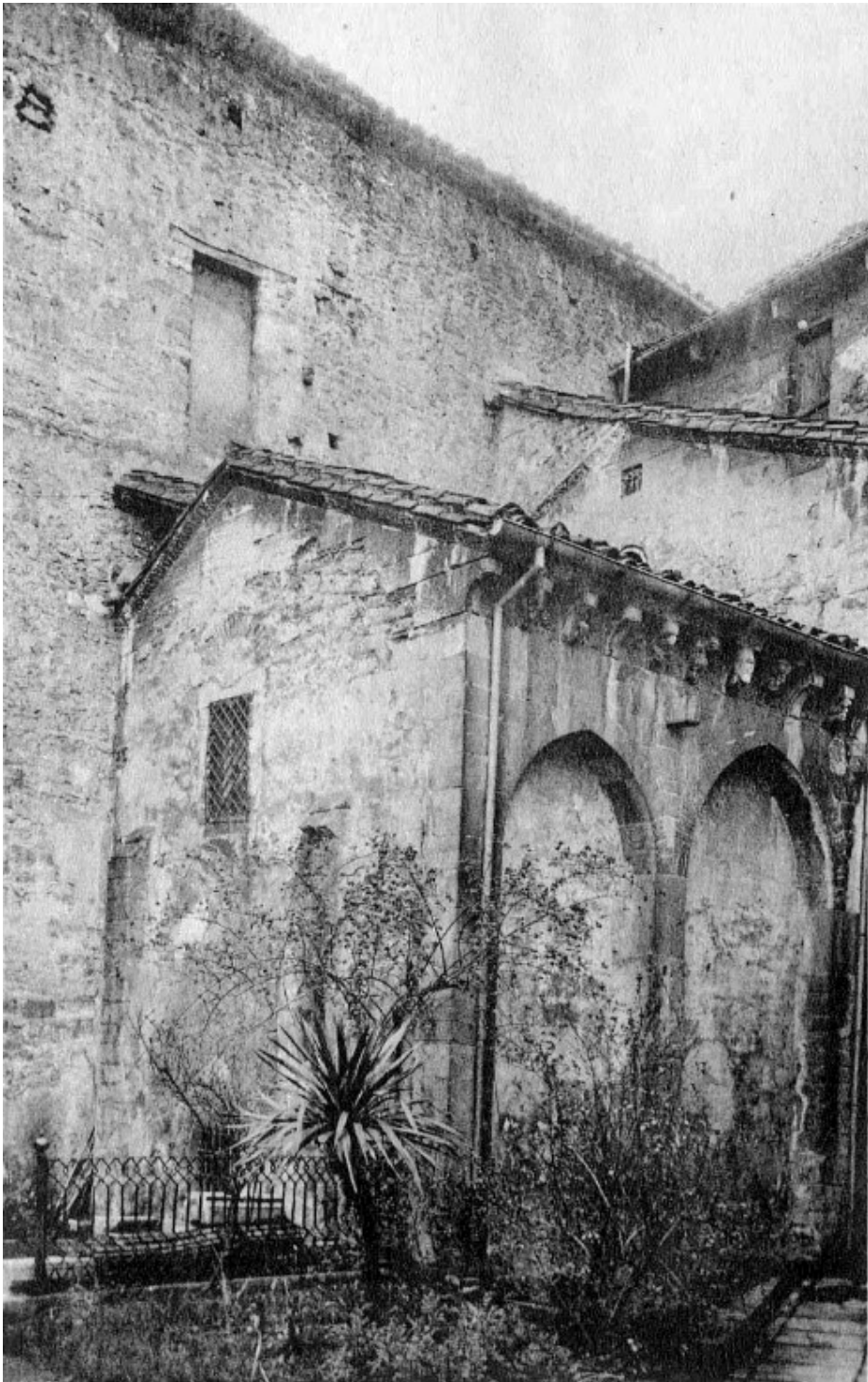

Fig. 1: Cámara Santa (exterior), Catedral de Oviedo. Hauser y Menet, hacia 1930. Archivo Municipal de Oviedo 
de Montjuic entre el 20 de mayo de 1929 y el 15 de enero del año siguiente ${ }^{4}$. En aquella ocasión, se consumó la primera salida de la ciudad de Oviedo de algunos de sus mayores bienes culturales. Desde la Catedral de San Salvador fueron trasladados a la capital catalana, donde permanecieron durante más de medio año, aparte del Arca Santa ${ }^{5}$ (cat. 796, Sala XIII), la lauda del sepulcro de Ithacius (cat. 803, Sala IV), la Arqueta de Santa Eulalia (cat.

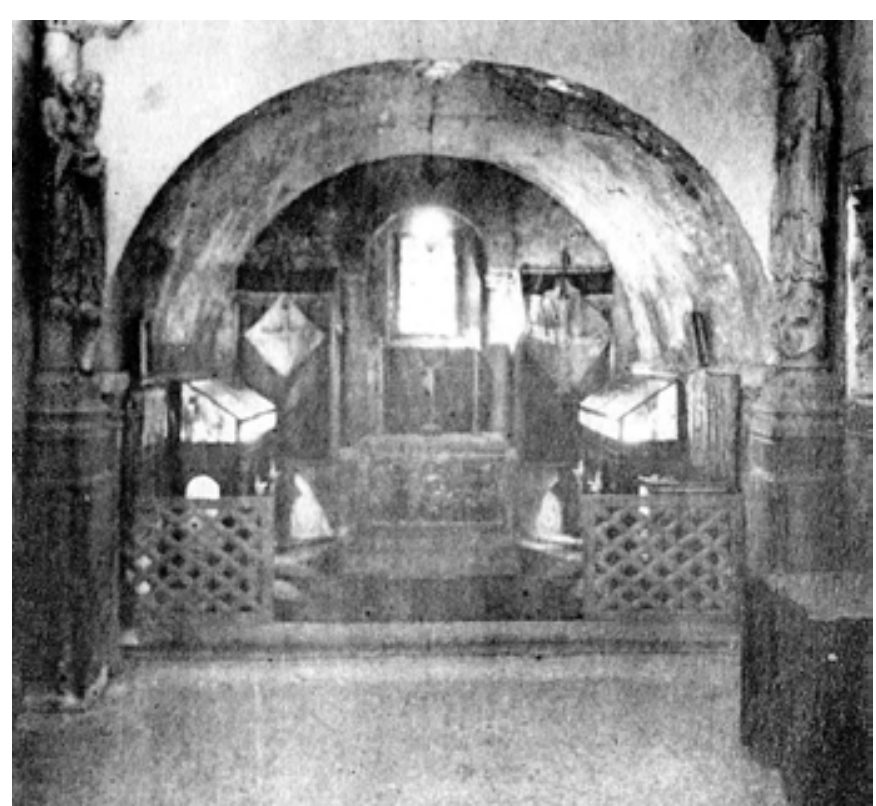

Hig. 2: Cámara Santa (interior), Catedral de Oviedo. Hauser y Menet, 1930. Archivo Municipal de Oviedo

4 GÓMEZ-MORENO, M. (Dir.): Exposición Internacional de Barcelona: El Arte en España. Guía del Museo del Palacio Nacional. Barcelona, Imprenta de Eugenio Subirana, 1929 [cat. exp.]. La muestra reunio un soberbio conjunto de antigüedades provenientes de todo el pás que sumó hasta un total de 4.899 piezas. Ya se refiere a esta exposición el erudito arqueólogo GÓMEZ-MORENO, M.: «El Arca Santa de Oviedo documentada», Archivo Español de Arte, nº 69, 1945, p. 125

5 GÓMEZ-MORENO, M. (Dir.): Exposición Internacional de Barcelona: El Arte en España. Guía del Museo del Palacio Nacional, op. cit., p.136.
802 y 806, Salas VI y XVII), la Cajita Eucarística del Obispo Ariano (cat. 798, Sala VII), las dos laudas sepulcrales de la Cripta de Santa Leocadia (cat. 804 y 805, Sala XIV), el Díptico Consular de Apión ${ }^{6}$ (cat. 799, Sala II) y el propio emblema del templo y de la diócesis, la Cruz de los Ángeles (cat. 797, Sala IV), entre otros objetos.

Tras su devolución en el inicio del año 1930, la tranquila presencia de esta obra maestra de la orfebrería hispana se vio pronto truncada por lamentables sucesos. Así, el 11 de octubre de 1934, una letal carga de dinamita alojada en el piso inferior de este martyrium hizo que todas las joyas y reliquias se precipitaran hasta el mismo suelo de la Cripta de Santa Leocadia y se entremezclaran con escombros y cascotes provenientes del suelo, los muros y hasta la bóveda celeste de la Capilla de San Miguel $^{7}$. Allí, la pudo contemplar, días más

6 Este espectacular díptico de marfil ejecutado el año 539 nunca ha estado vinculado al tesoro catedralicio, pese a llevar en Oviedo desde una fecha próxima al año 1300. Aunque en ocasiones se ha guardado en la Cámara Santa, ha debido pasar por las diferentes y sucesivas sacristías del templo, desde la Baja Edad Media en adelante, pues se le dio por largos siglos una utilidad asociada a la liturgia de la catedral. El día primero del año era el soporte para la hoja donde se escribían las fiestas movibles del año litúrgico. En 1934, el díptico se encontraba en el Archivo Capitular. Véase LLANO AMPUDIA, A. de: Pequeños Anales de 15 días. La Revolución en Asturias. Octubre 1934. Oviedo, 1935, p. 80. Es claro que tanto la Ć́m marfil véase la completa ficha catalográfica redactada por los doctores Yayoi Kawamura y César García de Castro e incluidos en BARÓN, J. et. al.: Museo de la Iglesia Oviedo. Catálogo de sus Colecciones. Oviedo, Museo de la Iglesia, 2009, pp. 76-78.

La historiografía acerca de este lamentable episodio es muy amplia. Consúltese el conmovedor relato en: LLANO AMPUDIA, A. de: Pequeños Anales de 15 días. La Revolución en Asturias. Octubre 1934, op. cit., pp. 69 y 70. Llano sitúa la exposición el 11 de octubre a las 8 de la mañana. Por otra parte, en el documentado texto del profesor De la Madrid se recoge la curiosa disparidad existente acerca de la misma fecha de la voladura de la Cámara Santa, que varios autores sitúan al día siguiente, 12/10/1934 (p. 265) Consúltese MADRID ÁLVAREZ, V de la: La Catedral de Oviedo. I. Historia y restauración. Oviedo, Ediciones Nobel, 1999, vol. 1, pp. 261 y ss. Ya en el acta de la sesión plenaria de la Academia de Bellas Artes de San Fernando donde se abordó la cuestión de la destrucción de la Cámara Santa apenas un mes después de los hechos, se indicaba que «la prensa se ha ocupado extensamente de otros muchos aspectos trágicos de la revolución no lo ha hecho de los referentes a los enormes destrozos artísticos». Véase Archivo Academia de Bellas Artes de San Fernando (en adelante ARABASF), Sign. 3-114 (1932-1935), Acta de la Sesión Ordinaria celebrada el lunes día 19 de noviembre de 1934, f. 572. Por tanto, el silencio y la confusión vivida en esos dís en la capital asturiana han desdibujalo inchso la fecha misma de la terrible deflagr de 1934. Vease HEVIA GRANDA, V. y FERNANDEZ BUELTA, J. Ma: «La Cámara Santa de Oviedo. Su primitiva construcción, su reconstrucción y su reconstrucción», Boletín del Instituto de Estudios Asturianos, nº 6, 1949, p. 51 . 
tarde, el arqueólogo e historiador Manuel Gómez-Moreno ${ }^{8}$ (1870-1970), comisionado junto al arquitecto Alejandro Ferrant $(1897-1976)^{9}$ mediante una autorización ministerial, junto al escultor local Víctor Hevia Granda $(1885-1957)^{10}$. Tras las delicadas labores de desescombro de la Cámara Santa, se aseguró la endeble estructura, que se mantuvo milagrosamente en pie incluso durante la guerra civil.

Respecto al contenido, a los múltiples fragmentos de la escultura monumental tardorrománica del Apostolado y el Calvario (s. XII) y a los marfiles, cajas y piezas de orfebrería -incluidas las que integran el Tesoro de la Monarquía Asturiana-, se inició el lento camino hacia la recuperación de la normalidad del lugar. Se sucedieron los demoledores informes de los técnicos especialistas, ante lo que se reaccionó de forma inmediata para disponer la reconstrucción del monumento (Alejandro Ferrant), que se encontró con e desarrollo de una guerra devastadora, lo cual retrasó y modificó (Luis Menéndez Pidal) notablemente los planes ya iniciados ${ }^{11}$.
8 Consúltese un completo perfil biográfico y profesional del arqueólogo Manuel Gómez-Moreno en GARCÍA CUETOS, Ma P.: «La renovación de la Historia de la Arquitectura y del Arte en las primeras décadas del siglo XX: Manuel Gómez-Moreno», en BIEL IBÁÑEZ, Mª P. y HERNÁNDEZ MARTíNEZ A. (Coords.): Lecciones de los maestros: aproximación histórico-crítica a los grandes historiadores de la arquitectura española. Zaragoza, Instituto Fernando el Católico, 2011, pp. 125-158.

9 GÓMEZ-MORENO, M. «El Arca Santa de Oviedo documentada», Archivo Español de Arte, nº 69, 1945, p. 126.

10 Sobre la labor de Hevia a cargo de las obras de recuperación de la escultura de la Cámara Santa tras el desastroso acontecimiento referido, véase HEVIA OJANGUREN, P.: «Víctor Hevia: El estudio y los talleres del artista. Claustro de San Vicente-Cámara Santa-Sala Capitular», en LLORDÉN MIÑAMBRES, M. y MENÉNDEZ LLANA, J.M. (Eds.), I Congreso de Estudios Asturianos, vol. V, 2007, Oviedo, Rea Instituto de Estudios Asturianos, pp. 177-1999.

11 Consúltense las investigaciones de García Cuetos tanto en torno a las labores de recuperación de arquitectura altomedieval asturiana (incluida la Cámara Santa), como en lo concerniente a las figuras de los arquitectos Ferrant y Meńndez Pidal: GARCíA CUETOS, Ma P. wLa restauración del Preromitad del siglo XX", en HEVIA BLANCO, J. (Coord.): La intervención en la arquitectura prerrománica asturiana. Oviedo, Universidad de Oviedo, 1997, pp. 97-118 y 119-136; GARCÍA CUETOS, Ma P.: Prerrománico Asturiano: historia de la arquitectura y restauración (1844-1976). Oviedo, Sueve, 1999

\section{EL ARCA SANTA A PARTIR DE OCTUBRE DE 1934: RECUPERACIÓN Y RESTAURACIÓN EN MADRID}

Mientras, el edificio fundacional de la Universidad de Oviedo (s. XVI) había sido pasto de las llamas el 13 de octubre de 1934 y con ello su riquísima biblioteca (s. XVIII) (Figs. 3-4) ${ }^{12}$ Ante esta gravísima situación, se constituyó la Asociación de Antiguos Alumnos y Amigos de la Universidad de Oviedo con el ánimo de avanzar en la recomposición del edificio y de su patrimonio bibliográfico ${ }^{13}$.

La minuciosa recogida y clasificación de los pedazos en que había quedado la Cámara Santa bajo la supervisión de Gómez-Moreno ${ }^{14}$, concluyó el 6 de noviembre de 1934. Tres días más tarde, el erudito arqueólogo dio cuenta de sus trabajos en la sede de la Academia de la Historia ${ }^{15}$. Poco después, el día 19, estuvo también presente en la sesión plenaria de la Academia de Bellas Artes de San Fernando, que reunida en su salón escuchó atenta y hasta contempló las terribles imágenes del desastre acontecido en Oviedo el mes anterior ${ }^{16}$. Curiosamente, aparte de la detallada intervención del arqueólogo, otro de los miembros del Pleno, el señor Herrero (director del Museo de Reproducciones Artísticas) apunto que «sería muy conveniente... traer a Madrid los objetos de la Cámara Santa para su reparación» ${ }^{17}$. Sin embargo, Gómez-Moreno ya tenía en su poder no solo el Arca, sino también un buen número de las piezas que conformaban uno de los más importantes tesoros catedralicios españoles.

12 RODRÍGUEZ ALVAREZ, R.: «La revolución de 1934 y sus consecuencias en la Universidad de Oviédo», Boletín de la Fundación Emilio Barbón, nº 3, 2019, p. 53 y ss.

13 Ibid., pp. 53 y 55. La primera reunión de la agrupación tuvo lugar en Madrid el 7 de noviembre de 1934 bajo la presidencia de Melquíades Álvarez y Posada (1864-1936), quien diera a conocer la existencia de la biblioteca de Roque Pidal en Madrid, con quien se negoció su venta en 1935.

14 La llegada de Gómez-Moreno a Oviedo para hacerse cargo de las obras tuvo lugar a 25 de octubre de 1934

15 Léase el detallado informe de los sucesos acontecidos en Oviedo y de los trabajos iniciales que, redactado por Manuel Gómez-Moreno y acompañados por un espectacular reportaje fotográfico, se expusieron en Archivo de la Real Academia de la Historia, Acta de la sesión del viernes 9 de noviembre de 1934, Boletín de la Academia de la Historia, t. 105, 1934, pp. 599-610.

16 El día 12 del mismo mes, justo una semana antes, Manuel Gómez-Moreno ya se encontraba en Madrid, pues asiste nuevamente al Pleno de la Academia y en aquella ocasión anunció que informaría de pcurrido en Oviedo $y$ de su trabjo en la sesín siguiente. Seguramente estaria pensanto en eabor cu inform $y$ en el revla do las sobrecogedoras fotografís con su ARABASI, Sign. 3-114 (1932-1935), Acta de ha Sesion Orinaia celebrada el lunes da 12 de noviembre de 1934, f. 563; Sign. 3-114 (1932-1935), Acta de la Sesión Ordinaria celebrada el lunes día 19 d noviembre de 1934, ff. 570-573. 


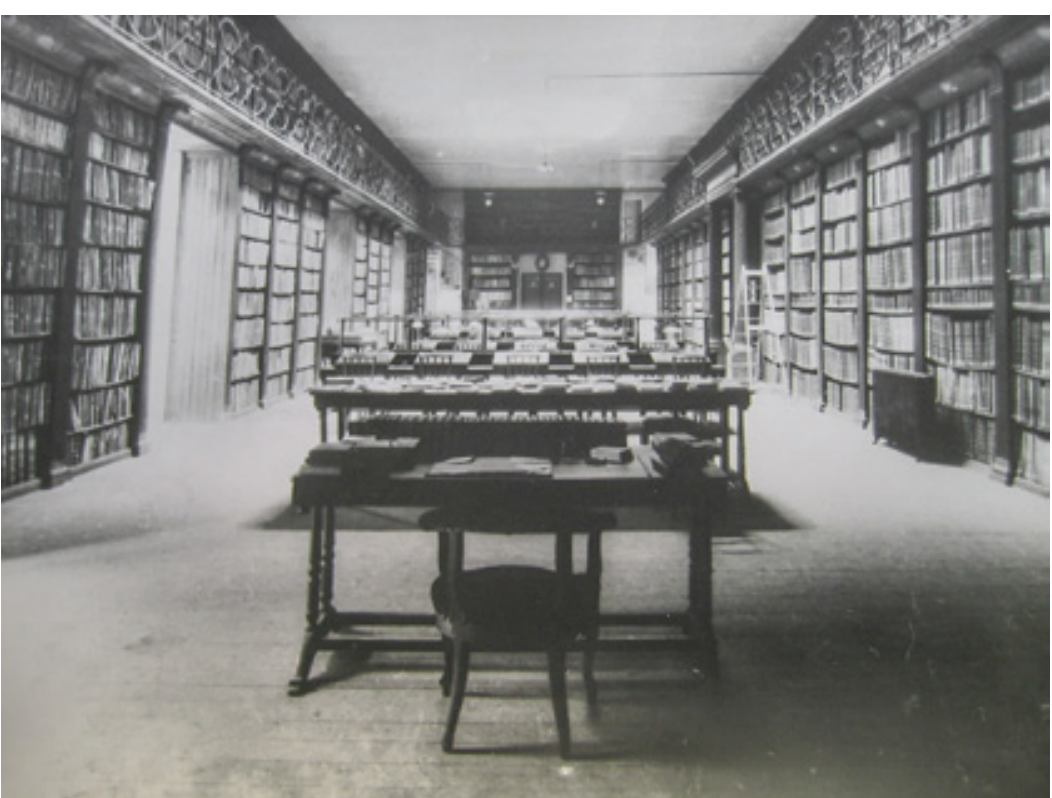

Fig. 3: Biblioteca de la Universidad de Oviedo, ante.1934. Archivo Histórico de la Universidad de Oviedo

Una vez reunidos los fragmentos en que quedó cuarteada el Arca, y debidamente asegurados, se produjo la entrega ${ }^{18}$ al profesor Manuel Gómez-Moreno (1870-1970) para proceder a su restauración en Madrid, que se llevó a cabo en el Instituto Valencia de Don Juan, entidad privada dirigida esos años por el arqueólogo granadino y que tenía su sede en la céntrica calle Fortuny de la capital. Concluidos los trabajos, Gómez-Moreno comunicó al Patronato del Museo del Prado «que se halla terminada la restauración del Arca Santa de la Catedral de Oviedo» ${ }^{19}$

17 ARABASF, Sign. 3-114 (1932-1935), Acta de la Sesión Ordinaria celebrada el lunes día 19 de noviembre de 1934, f. 572 .

18 Cuesta fecha la entrega el 12 de noviembre de 1934. Véanse: CUESTA FERNÁNDEZ, J. y ARIAS DEL VALLE, R.: Guía de la Catedral de Oviedo. Oviedo, Asociación de Amigos de la Catedral de Oviedo, 1995, p. 193; GÓMEZ-MORENO, M. «El Arca Santa de Oviedo documentada», op. cit., p.

126. Gómez-Moreno también habla de esa misma fecha. Revísese también la actualizada biografía redactada por MEDEROS MARTÍN, A.: «Manuel Gómez-Moreno y Martínez», en Real Academia de lo Historia. Diccionario Biográfico electrónico. http:dba.rah.es/ (Consultado el 01/05/2020).

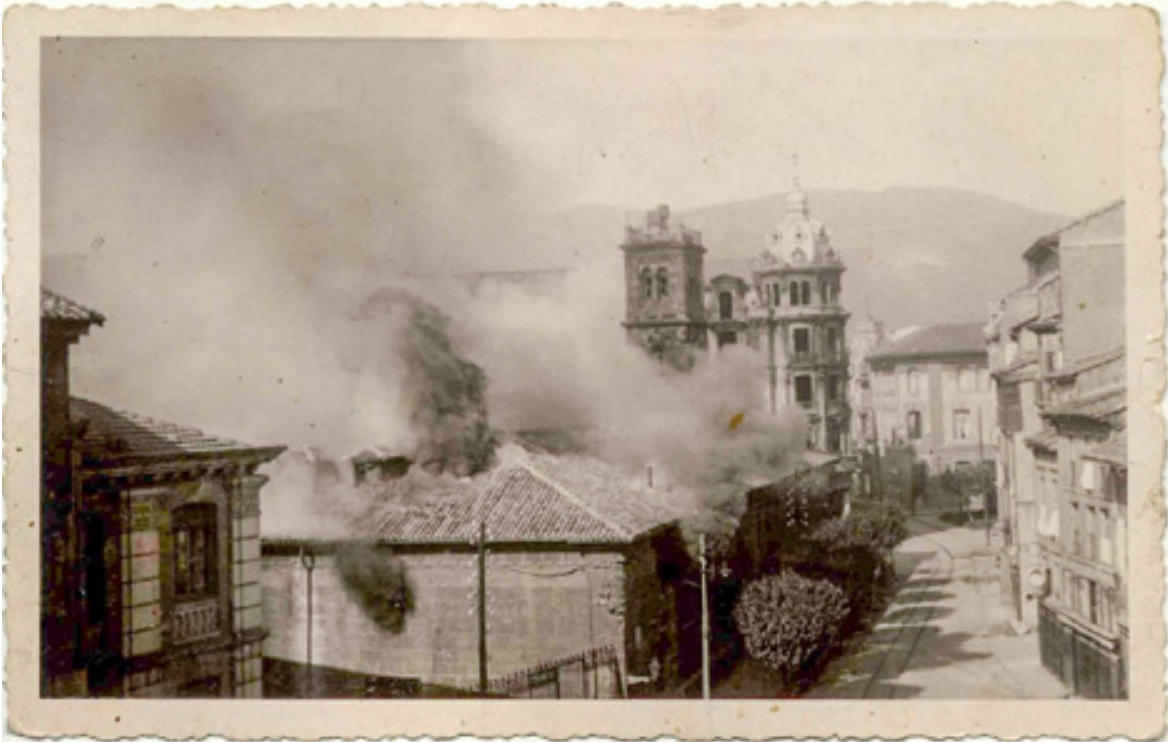

Fig. 4: Universidad en llamas durante los Sucesos de Octubre de 1934. Archivo Municipal de Oviedo

La recomposición del Arca en Madrid, fue materializada por Victoriano Serrano bajo la supervisión de M. Gómez-Moreno ${ }^{20}$. El Cabildo ovetense había cedido igualmente para su reintegración material otras piezas aparte del Arca Santa, entre las que sobresalía la Arqueta de Santa Eulalia de Mérida ${ }^{21}$. Todas ellas se encontraban en el "Camarín» en el momento de la explosión, incluida la espectacular pieza que guarda los restos de la mártir extremeña, que desde 1697 contaba con su propia capilla funeraria, en la que se acomodó

19 Archivo Museo Nacional del Prado (en adelante AMNP), Acta 345 de 16 de mayo de 1935, f. 56

20 Victoriano era conserje del Instituto y al tiempo poseía conocimientos de carpintería. Véase GÓMEZ-MORENO, M. «El Arca Santa de Oviedo documentada», op. cit., p. 127. El Instituto Valencia de Don Juan no conserva testimonio alguno acerca de la restauración ni tan siquiera de la presencia del Arca y las demás piezas en su sede. Tampoco se ha podido localizar, hasta la fecha, información alguna acerca del ayudante de Gómez-Moreno.

21 Gómez-Moreno indica que se le hizo entrega de las piezas por Acuerdo Capitular de 12 de noviembre de 1934 (GÓMEZ-MORENO, M. «El Arca Santa de Oviedo documentada», op. cit., p. 126), si bien en 
la valiosa arqueta a un tabernáculo ideado para ella por Juan García de Ascucha y Domingo Suárez de la Puente ${ }^{22}$. No obstante, la arqueta fue sometida a cambios de localización al igual que ocurrió con el lienzo (1639-1640) que hizo el pintor vallisoletano Diego Valentín Díaz (1586-1660) por encargo de la Catedral y que tuvo varios acomodos, incluido uno de los machones del deambulatorio hasta que allí se ubicara la magnífica escultura ejecutada el año 1743 por el celebrado escultor castellano Alejandro Carnicero (1693-1756), para instalarse definitivamente en la nueva Sacristía General, donde permanece.

Esta valiosa caja-relicario se puede afirmar que está ligada desde su misma materialización hacia el año 1100 a un lugar, la Cámara Santa, para el que fue realizada. Allí ocupó una localización preferente dada la importancia de las reliquias que siempre contuvo y en ese mismo emplazamiento, más de ocho siglos después, padeció los estragos de la destrucción, si bien muchos menos de los que podrían haber sido. Por tanto, la arqueta de Santa Eulalia, obra maestra absoluta de su tiempo, es, en realidad, una de las joyas históricas de la Cámara Santa ${ }^{23}$ y estuvo separada del recinto desde que el obispo Simón García Pedrejón ideara su capilla propia muy cerca de los pies del templo catedralicio, por lo que estuvo en su baldaquino (donde está actualmente) por más de tres siglos, si bien con algunas interrupciones temporales.

La nómina de piezas cuya custodia encomendó el Cabildo ovetense a Gómez-Moreno incluía también otras preseas que habían sufrido daños de diferente consideración: Cristo de Nicodemo, Díptico de Gundisalvo y la Cajita del Obispo Ariano ${ }^{24}$.

esa fecha se encontraba en el Pleno de la Academia de Bellas Artes y tres días antes hacía lo propio en l de la Academin de la Historia con lo que las piezas salieron de Oviedo entre el $7 \mathrm{y}$ el 8 de noviembre.

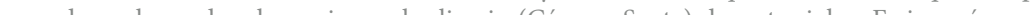
ocupado un lugar de relevancia en el relicario (Cámara Santa) durante siglos. Es inequívocamente la Arqueta de Santa Eulalia parte de un conjunto conformado por el Arca Santa, la Cajita del Obispo Ariano y el Cristo de Nicodemo. Todas estas preseas, próximas en el tiempo y con un elevado nivel artístico e historico, están estrechamente ligadas al célebre "Camarin de las Reliquias».

23 Allí la vio Ambrosio de Morales en su conocido recorrido por el Norte de España el año 1572. Véas MORALES, A. de: Viage de Ambrosio de Morales por orden del rey Phelipe II a los reynos de León y Galicin $y$ Principalo diage de Ambrosio de Morales por orden del rey Phelipe II a los reynos de Lec irgo para la ideación y ejecución del proych

24 GÓMEZ-MORENO, M. «El Arca Santa de Oviedo documentada», op. cit., p. 127. De todo esto da cuenta el propio Gómez-Moreno, si bien no se conoce si son devueltas en 1935 o después de la guerra civil pues no se vuelven a mencionar en la documentación a la que hemos tenido acceso

\section{LA EXPOSICIÓN DEL ARCA SANTA EN EL MUSEO DEL PRADO (1935)}

El 16 de mayo de 1935 el Patronato del Museo del Prado ${ }^{25}$, del que también era miembro Gómez-Moreno, incluyó en el acta de su reunión ordinaria su propuesta para «que se exhiba al público en una de las salas bajas» ${ }^{26}$. Así, en una fecha que aún no se puede precisar, el Arca Santa se trasladó desde el Instituto Valencia de Don Juan para ser presentada en compañía de la Arqueta de Santa Eulalia. El objeto de esta exposición temporal, cuyo acceso se efectuaba mediante el pago de una entrada de 0,50 cts., fue «la adquisición de libros con destino a la biblioteca de la Universidad de Oviedo $»^{27}$. Por tanto, esta muestra tuvo una motivación clara a favor de la recomposición del patrimonio bibliográfico perdido en la Revolución de Octubre de 1934, al tiempo que se publicitaban en el Prado los esfuerzos realizados para la recuperación del relicario. Curiosamente, una de las principales joyas de la Cámara Santa, profundamente dañada en los mismos días y una vez restaurada, sirvió para recaudar fondos con que surtir de libros de nuevo al principal centro bibliográfico de Asturias.

La exposición se abrió al público el día 23 de mayo de $1935^{28}$ en el arranque de la planta baja del museo ${ }^{29}$. En lo concerniente al montaje, el Arca Santa (Fig. 5) se presentó sobre una tarima de madera, mientras que la Caja de Santa Eulalia (Fig. 6) se colocó en un pedestal

25 La dirección del Museo Nacional del Prado correspondió entre los años 1931 y 1936 al escritor y político ovetense Ramón Pérez de Ayala (1880-1962), quien había estudiado Derecho en la Universidad de Oviedo, siendo discípulo de Leopoldo Alas Clarín. No obstante, dada su condición de Embajador de la República Española en Inglaterra, el subdirector de la institución, Francisco Javier Sánchez Cantón, ejerció de director interino hasta el 4 de junio de 1936, en que Pérez de Ayala toma posesión del cargo, hasta que Picasso le sustituye en el puesto. Consúltese: PÉREZ DE AYALA, J.: «Pérez de Ayala y Fernández del Portal, Ramón», Museo Nacional del Prado. Enciclopedia del Prado. https://www.museodelprado.es (Consultado el 24/05/2020); AMORÓS GUARDIOLA, A «Ramón Pérez de Ayala», Real Academia de la Historia. Diccionario Biográfico electrónico. http:dbarahes/(Consultado el 24/05/2020).

27 Recogido en la carta remitida por la Secretaría del Patronato a 22 de mayo de 1935 y dirigida al secretario de la Asociación de Antiguos Alumnos y Amigos de la Universidad de Oviedo. Documento conservado en la carpeta AMNP, Caja 91, Legajo 1501. Expte. 110001. Consúltese también AMNP, Acta 345 de 16 de mayo de 1935, f. 56.

28 Ya habíamos avanzado esta fecha para la historia de la pieza en APARICIO VEGA, Juan Carlos: «Un arca urbana para el Arca Santa», La Nueva España, Oviedo, 13 de agosto de 2017.

29 AMNP, Caja 4016, Exp. 10001, f. 43. En este documento custodiado en el Museo del Prado se recogen numerosas noticias de prensa recortadas, algunas sin fuente ni fecha exacta. Véase particularmente «Museo del Prado. Exposición del Arca Santa y de la Caja de Santa Eulalia de la Cámara Santa de Oviedo». En esta noticia se alude a la intervención recién realizada en el Instituto Valencia de Don Juan. Consúltese también, «Las reliquias de la Catedral de Oviedo fueron expuestas esta mañana en el 


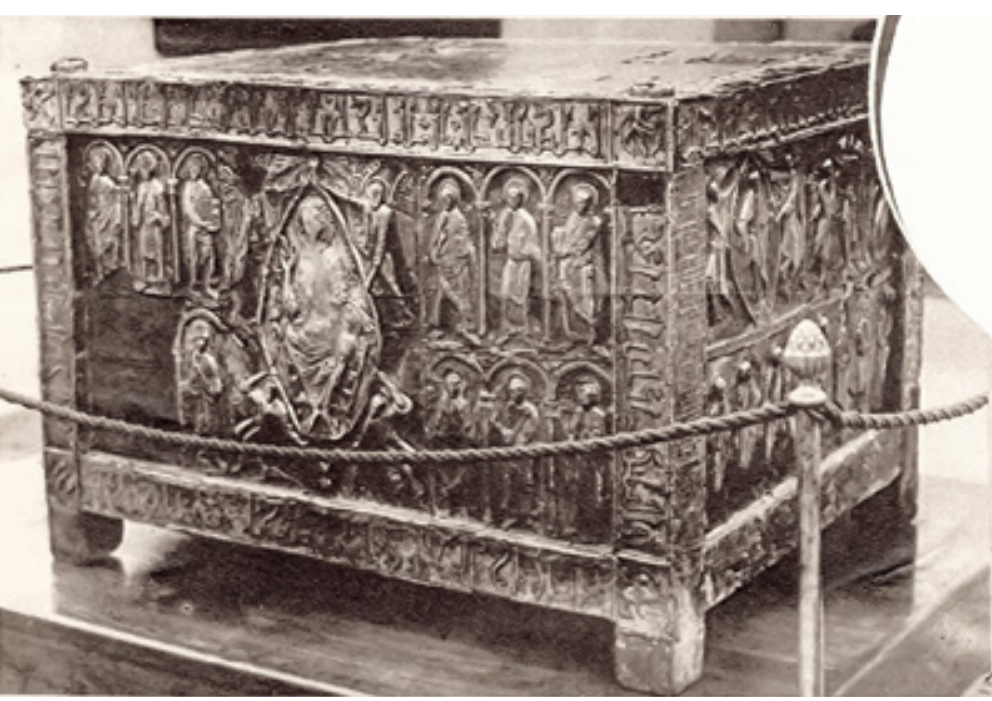

Fig. 5: Arca Santa en el Museo del Prado, 23 de mayo de 1935. Archivo del Museo Nacional de Prado, Caja 4016, Exp. 10001, f. 48. Ahora, 24 de mayo de 1935

pétreo ${ }^{30}$. Convivieron durante esos días las piezas ovetenses con un tapiz del legado por el Duque de Tarifa, expuesto igualmente en la sala de acceso a la selección del fondo escultórico $^{31}$. Se trataba del espacio conocido entonces como sala $\mathrm{L}$, en el vestíbulo ${ }^{32}$ de la rotonda de la planta baja del Museo del Prado, la zona más novedosa del centro, inaugurada el año 1934 en el marco de un Congreso de Museografía, cuyas obras de acondicionamiento estuvieron a cargo del arquitecto conservador del museo Pedro Muguruza (1893-1952) ${ }^{33}$.

Museo del Prado», La Nación, Madrid, 23 de mayo de 1935, acompañadas de magníficas imágenes de la muestra, incluso de las cartelas explicativas. AMNP, Caja 4016, Exp. 10001, f. 45

30 Véanse las imágenes tomadas por el fotógrafo Díaz Casariego y publicadas en La Nación, Madrid, 23 de mayo de 1935. AMNP, Caja 91, Legajo 1501, Exp. 110001, f. 45.

31 Diario de Madrid, 23 de mayo de 1935. AMNP, Caja 4016, Exp. 10001, f. 46.

32 Aparece ampliamente recogido en la prensa de la época. La Época, Madrid, 23 de mayo de 1935; Diario de Madrid 23 de

33 Véanse: PÉREZ DE AYALA, J. «Pérez de Ayala y Fernández del Portal, Ramón», en Museo Naciona del Prado, Enciclopedia del Prado. Disponible en https://www.museodelprado.es. La celebración del Congreso Internacional de Museografía, cuya organización estuvo a cargo de la Sociedad de Naciones,

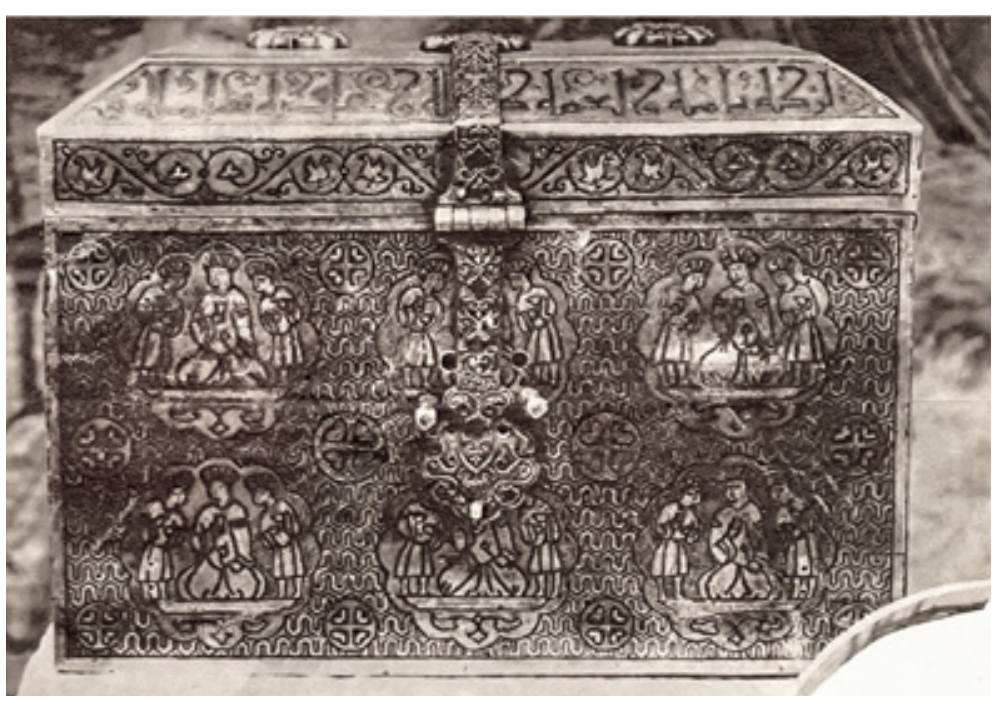

Fig. 6: Arqueta de Santa Eulalia de Mérida en el Museo del Prado, 23 de mayo de 1935. Archivo del Museo Nacional del Prado, Caja 4016, Exp. 10001, f. 48. Ahora, 24 de mayo de 1935

La Junta de Gobierno de la Asociación de Antiguos Alumnos y Amigos de la Universidad de Oviedo acordó en su reunión del 1 de junio de 1935 agradecer al Patronato del Museo del Prado la exposición referida en sus instalaciones y ratificó que los fondos recaudados irían destinados a la «adquisición de libros para la futura Biblioteca de la Universidad de Oviedo», dado que la institución, tras más de tres siglos de historia, se había quedado sin su importante colección bibliográfica ${ }^{34}$. La exposición obtuvo un total de 3.510 visitas, lo que supuso un reembolso para la asociación universitaria, promotora de la muestra, de 1.755 pesetas $^{35}$.

tuvo su sede en la Real Academia de Bellas Artes de San Fernando.

34 Véase la comunicación de José María Serrano al Secretario-Interventor del Museo Nacional del Prado, 12/06/1935. AMNP, Caja 91, Legajo 1501. Exp. 110001.

35 En su carta, el director interino del museo, Francisco Javier Sánchez Cantón (1891-1971) acuerda la entrega íntegra del dinero recaudado, pero apunta que el gasto se haga a favor de «libros de Arte Español con destino a la Biblioteca de esa Universidad». Véase la carta del director interino del Museo Nacional del Prado a José Serrano, 13/09/1935. Seguramente la muestra había finalizado hacia el 12 de junio, por lo que su duración se aproximó a las tres semanas. 
Cabe pensar que aparte de M. Gómez-Moreno, cuya labor de recuperación del Arca en Madrid resultó esencial, se contó con la activa colaboración de Ramón Pérez de Ayala (18801962), que ocupaba la dirección del museo. Otro apoyo clave en relación a esta exposición fue el de José María Serrano Suárez (1900-1973) ${ }^{36}$ (Fig. 7), catedrático de Derecho de la Universidad de Oviedo, que mantuvo una estrecha relación con Pérez de Ayala ${ }^{37}$ y se implicó de forma activa en calidad de secretario de la Asociación de Antiguos Alumnos y Amigos de la Universidad de Oviedo en la reintegración patrimonial de la institución académica ${ }^{38}$.

\section{EL ARCA SANTA DESPUÉS DE LA EXPOSICIÓN. MUSEO ARQUEOLÓGICO} NACIONAL: DEPÓSITO Y REPRODUCCIÓN

La preciada pieza románica fue trasladada, nuevamente en una fecha desconocida, desde el Museo del Prado al Museo Arqueológico Nacional, en la calle Serrano, donde permaneció por un tiempo indeterminado ${ }^{39}$. Allí «se la vació ${ }^{40} \mathrm{y}$ fotografió ampliamente» ${ }^{41}$. Resulta una verdadera incógnita este período en Madrid del Arca ya restaurada. Nada se sabe con

36 Sobre su vida ha trazado un magnífico retrato TOLIVAR FAES. J : Nombres $y$ cosas de las calles de Oviedo. Oviedo, Avuntamiento de Oviedo, 1992, pp. 159-160. También recoge su perfil humano y profesional CORONAS GONZÁLEZ, J.R.: Las Asociaciones de Antiguos Alumnos y Amigos de la Universidad de Oviedo de 1906 y 1934. Oviedo, Asociación de Antiguos Alumnos y Amigos de la Universidad de Oviedo, 2007, p. 131 y ss.

37 Los fondos documentales y bibliográficos del escritor ovetense y los de la Familia Serrano se encuentran actualmente en la Biblioteca de Asturias Ramón Pérez de Ayala. Véase «Biblioteca de Asturias Ramón Pérez de Ayala», en Biblioasturias.com, 12/02/2016. http://www.biblioasturias.com/biblioteca-de-asturias-ramon-perez-de-ayala/ (Consultado el 03/05/2020). Recientemente, se ha incrementado el fondo que interrelacion a ambas persona que interestales

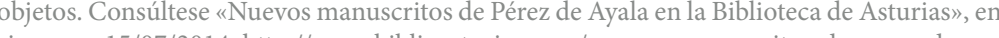
rias.com, 15/07/2014. http://www.biblioasturias.com/nuevos-manuscritos-de-perez-de-ayala-en-la-bi blioteca-de-asturias/ (Consultado el 03/05/2020)

38 A modo de manifiesto, la Asociación publicó un primer folleto en que expresaba su voluntad de devolver a la Universidad su materialidad. Véase Asociación de Antiguos y Alumnos de la Universidad de Oviedo, hacia 1934

39 En el archivo del Museo Arqueológico Nacional (en adelante MAN) no consta el depósito del Arca Santa, donde, sin embargo, tuvo que permanecer durante un largo período de tiempo

40 El vaciado para hacer una reproducción se hizo inequívocamente en el MAN. Gómez-Moreno indica que la copia se hizo bajo la tutela de Cayetano de Mergelina (1890-1962), director de la institución durante la guerra civil. GÓMEZ-MORENO, M. «El Arca Santa de Oviedo documentada», op. cit., p. 127. 41 GÓMEZ-MORENO, M. «El Arca Santa de Oviedo documentada», op. cit., p. 127

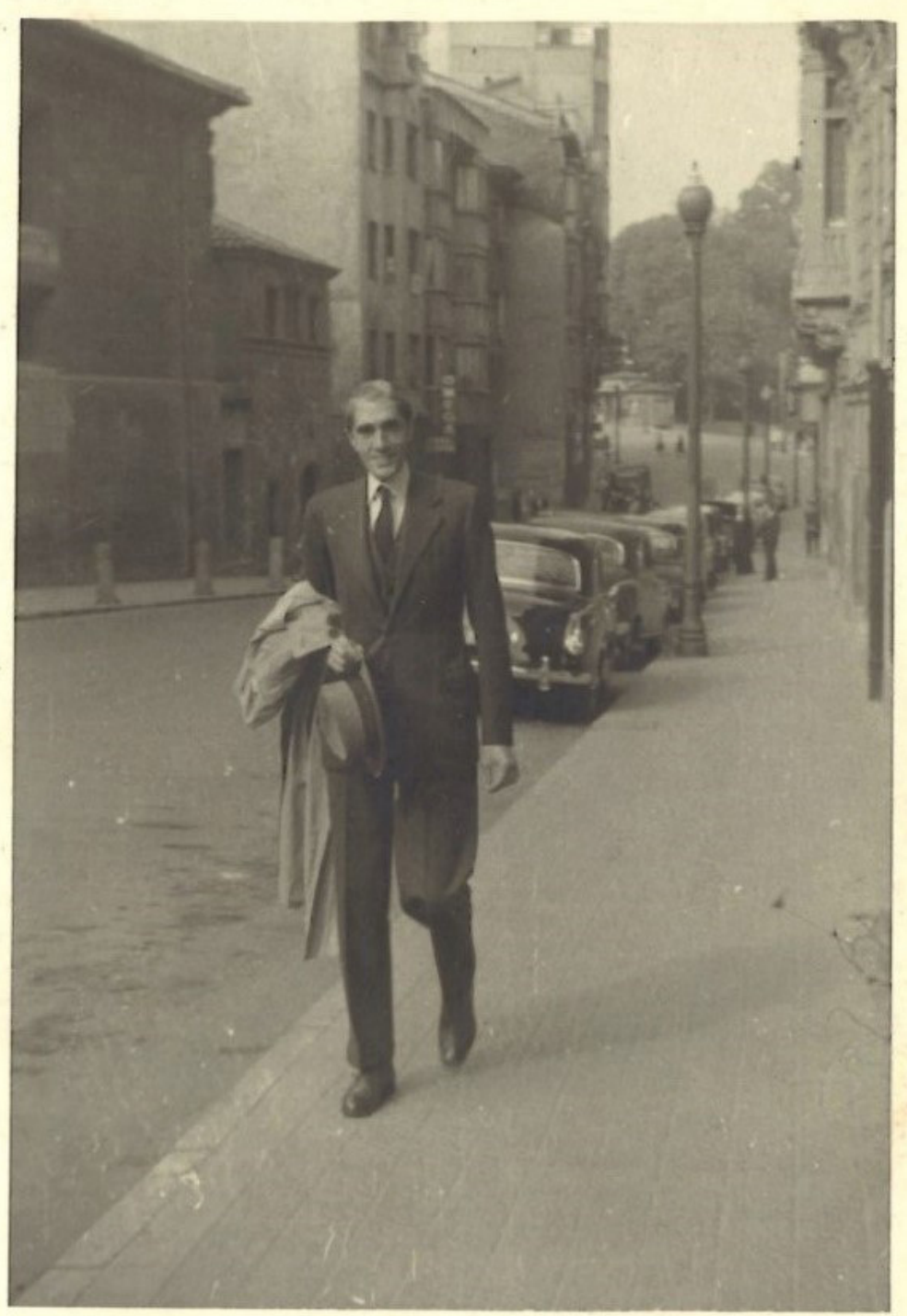

Fig. 7: José María Serrano frente a la Universidad de Oviedo, 1957. Biblioteca de Asturias Ramón Pérez de Ayala 
seguridad ni tan siquiera del lugar en que se custodió entre junio de 1935 y junio de $1939^{42}$ Lo único claro es que el 12 de abril de $1938^{43}$ la Junta Central del Tesoro Artístico ordenó que se preparase la pieza (y también la Arqueta de Santa Eulalia) para llevarla a Barcelona junto a otras obras que estaban almacenadas en el Museo del Prado. Si bien, se incumplió dicha orden ${ }^{44}$.

El Arca, tras permanecer en la capital al menos hasta el fin de la guerra civil, fue recogida por José Cuesta Fernández (1875-1966), en representación de la Catedral de Oviedo, «a los pocos días» ${ }^{45}$. La devolución del Arca Santa fue materializada el año $1939^{46}$, por lo que estaría fuera de la ciudad cerca de cuatro años y medio. Previamente, la pieza, que había servido para recaudar fondos para el restablecimiento de la Biblioteca Universitaria, fue empleada en un acto propagandístico del nuevo régimen que había salido victorioso en la guerra. Así, formó parte de la ceremonia que siguió al Desfile de la Victoria y que tuvo lugar en el centro de Madrid el 20 de mayo de 1939. En la fastuosa Iglesia de Santa Bárbara, conocida como «Las Salesas Reales», se colocó en el presbiterio según dispuso la Jefatura del Estado ${ }^{47}$.

Durante tan larga estancia en Madrid, el Arca Santa había sido sometida a un vaciado con la finalidad de realizar una reproducción, que perteneció al Museo Arqueológico Nacional, el lugar donde se materializó. Curiosamente, la presencia del original no dejó huella documental alguna, pero sí la de su copia. En sesión del 25 de marzo de 1940, el Patronato

42 Pudo guardarse en alguno de los diferentes depósitos de la Junta del Tesoro Artístico, que entre los año 1938 y 1939 destinaban el Museo Arqueológico, sito en el Palacio de Bibliotecas y Museos, a albergar, entre otro tipo de piezas las de orfebrería y marfiles, luego es muy probable que las joyas de la Catedra de Oviedo estuvieran por algún tiempo en la calle Serrano de Madrid. Véase AMNP, Caja 135, Exp. 1154. En este documento incluso se incluve un listado de depósitos y se referencian como los tres depósitos de máxima importancia en este orden: Museo Arqueológico Nacionaly Biblioteca, Museo estar siempre entre el MAN y el Prado.

3 ARGERICH, I. y ARA, J.: Arte protegido. Memoria de la Junta del Tesoro Artístico durante la Guerr Civil. Madrid, Instituto del Patrimonio Cultural de España y Museo Nacional del Prado, 2009, p. 55

44 Ibid., p.56.

45 CUESTA FERNÁNDEZ, J. y ARIAS DEL VALLE, R.: Guía de la Catedral de Oviedo. Oviedo, Asociación de Amigos de la Catedral de Oviedo, 1995, p. 193.

46 Ibid.

47 El templo se encuentra en General Castaños 2, muy cercana al Paseo de La Castellana. Había sido utilizado como almacén menor de objetos muebles recogidos por la Junta del Tesoro Artístico durante la guerra civil. La ceremonia religiosa contó con la presencia del Arca Santa de Oviedo, tal y como se recoge en Región, Oviedo, 21 de mayo de 1939. del Museo Arqueológico acordó ofrecer su fondo de negativos, entonces constituido por 129 vaciados, al Museo de Reproducciones Artísticas, «entre los que figura uno fidelísimo del Arca Santa de la Catedral de Oviedo» ${ }^{48}$. El 30 de abril del mismo año «los empleados de la Casa Garrouste» recogen la copia del Arca Santa ${ }^{49}$. Sin embargo, el MAN debía conservar otra reproducción pues ésta es requerida para formar parte de la Exposición de Arte Religioso celebrada el año 1946 en los Palacios de Exposiciones del Retiro madrileño ${ }^{50}$ Finalmente, se formalizó la cesión de una copia del Arca al Museo de Reproducciones Artísticas, que se incluyó en una selecta relación de obras cedidas por el mismo cauce el 2 de junio de $1953^{51}$. La pieza, en su versión en yeso policromado, se integró en la colección estable del Museo Nacional de Reproducciones Artísticas gracias a la entrega del mismo por parte del MAN el año $1940^{52}$. Por tanto, debió haber dos copias similares.

Por otra parte, la reproducción (quizás doble) ${ }^{53}$ de la pieza, se materializó siendo director del MAN Cayetano Mergelina y Luna ${ }^{54}(1890-1962)$ y ha pasado a pertenecer a los fondos del Museo Nacional de Escultura, ubicado en Valladolid, aunque aún permanece en Madrid almacenada a la espera de su traslado y puesta en valor en su nueva sede de la Casa del Sol ${ }^{55}$.

48 Archivo del Museo Arqueológico Nacional (en adelante AMAN), Expte. 140-38. Carta del Presidente del Patronato al Director General de Bellas Artes, Madrid, 25/03/1940.

49 AMAN, Expte. $140-38$

50 AMAN, Expte. 146-4A

51 AMAN, Expte. 1953-33. El Museo de Reproducciones Artísticas de Madrid, entonces alojado en el Casón del Buen Retiro, acabaría siendo el destino por un tiempo de una copia del Arca, desde la inmediata posguerra.

52 DIAZ LOPEZ, G.: «La nueva sala de arte medieval español del Museo de Reproducciones Artísticas» Academia. Boletín de la Real Academia de Bellas Artes de San Fernando, no. 4, 1952, pp. $498-499$

Este autor se refiere a la existencia de otro vaciado similar en el propio Museo Arqueológico.

53 En el relato del canónigo Cuesta sobre este episodio, éste vincula el encargo de la reproducción a la intención del Gobierno de trasladarla a Moscú. Añade además que Gómez-Moreno había solicitado el permiso oportuno para realizar la copia. Véase CUESTA FERNÁNDEZ, J. y ARIAS DEL VALLE, R. Guía de la Catedral de Oviedo, op. cit., p. 193.

54 Véase su perfil biográfico y profesional redactado LADERO GALÁN, A.: «Cayetano de Mergelina y Luna». http://www.man.es/man/museo/historia/personal/directores/mergelina (Consultado el 14/04/2020). Fue director entre el 20 de septiembre de 1937 y abril de 1939, lo que situaría la realización de la copia del Arca en este rango cronológico y confirmaría que el origina lo que sifepositado en elion de la copia

55 ALMAGRO GORBE, Ma Ja Cátogo del Arte Medieval Cristan. Madid, Museo Nacional de Reproduccones Artísticas, 1998, $\mathrm{p}$. 22 Alma Arte Medieval Cristino. Mrid Muco Nacional de la pieza por parte del Patronato del Museo Arqueológico. No se consigna la cronología exacta de realización de la copia de escayola patinada y policromada y tampoco se menciona una segunda copia. 


\section{LA DEVOLUCIÓN DEL ARCA SANTA}

La devolución del Arca Santa a la Catedral de Oviedo se consumó finalmente el 12 de junio de $1939^{56}$. De este modo, a las 23:15 horas de ese día, arribó a Oviedo la pieza, donde fue recibida por Arturo Sandoval. La expedición estaba comandada por el deán José Cuesta Fernández ${ }^{57}$, si bien apoyado por una figura esencial a lo largo de todo el proceso, el catedrático Serrano ${ }^{58}$, quien firmaría el día más arriba referido (sin concretar la hora) el recibí de recogida en el Museo del Prado (Fig. 8) en nombre del Cabildo de la Catedral y del Patronato para la reconstrucción del templo. Curiosamente, el documento es muy escueto y dice que «he recogido para trasladarla à Oviedo, la plataforma del Arca Santa» y no se refiere ni a la Arqueta de Santa Eulalia ni a las otras joyas del tesoro ovetense que sin duda la acompañaban ${ }^{59}$.

Las obras de reconstrucción del relicario debieron obligar a asegurar las piezas entretanto se materializaba el proyecto de recomposición a cargo de Luis Menéndez Pidal (1896-1975) y durante el episcopado de Manuel Arce Ochotorena (1879-1948), quien ocupó la sed ovetense entre 1938 y $1944^{60}$. El Arca pudo guardarse durante varios años (1939-1942) en la Sacristía General, seguramente en el «Cuarto de la Plata» ${ }^{61}$. En ocasiones puntuales, se exhibió en el presbiterio de la contigua Capilla de Santa María del Rey Casto ${ }^{62}$

56 En su artículo acerca del Arca Santa publicado en Archivo Español de Arte, Gómez-Moreno habla de 1940 y no da más detalles. Ello pudo deberse a que la pieza ya no estaba bajo su custodia y que parece totalmente desvinculado de su entrega al Cabildo. GOMEZ-MORENO, M. «El Arca Santa de Oviedo documentada», op. cit., p. 127. Véase también «El Arca Santa, otra vez en Oviedo», Región, Oviedo, 13 de junio de 1939. Entre los detalles de esta información periodística se habla de su llegada en un camión y que las piezas «estaban perfectamente empacadas».

57 Resultan esclarecedoras las declaraciones de Cuesta Fernández al diario Región en mayo de 1939, donde repasa el estado de los trabajos de reconstrucción y comenta que en Madrid para su restauración «figuran entre otras, el Arca Santa» y también menciona «las ricas urnas que, que guardan los cuerpos santos de los mártires Eulogio y Lucrecia, Julián y Serrano y Santa Eulalia de Mérida». Asimismo, dice que una vez restauradas, ya están «a salvo de la rapiña marxista». Región, Oviedo, 4 de mayo de 1939.

58 Serrano, cuyos papeles y libros se conservan en la Biblioteca de Asturias Ramón Pérez de Ayala, fue un de los integrantes del Comité ejecutivo para la reconstrucción de la Catedral de Oviedo, constituido el 4 de mayo de 1939, junto a José Cuesta, Guillermo Estrada y José Fernández Buelta. Además Serrano, como miembro de la comunidad universitaria, se mantuvo como la pieza clave en ambos escenarios, Catedral $y$ Universidad, por lo que se puede afrmar que es et verd bero nexo entre ambos asuntos, unidos en su desastrosa y dolorosa destrucción, pero también en el Museo del Prado aquella primavera de 1935. Un bien, ya recuperado, fue usado para alentar la reintegración ahora de la biblioteca.

59 AMNP, Caja 93, Legajo 1524, Exp. 01, doc. 02, f. 36

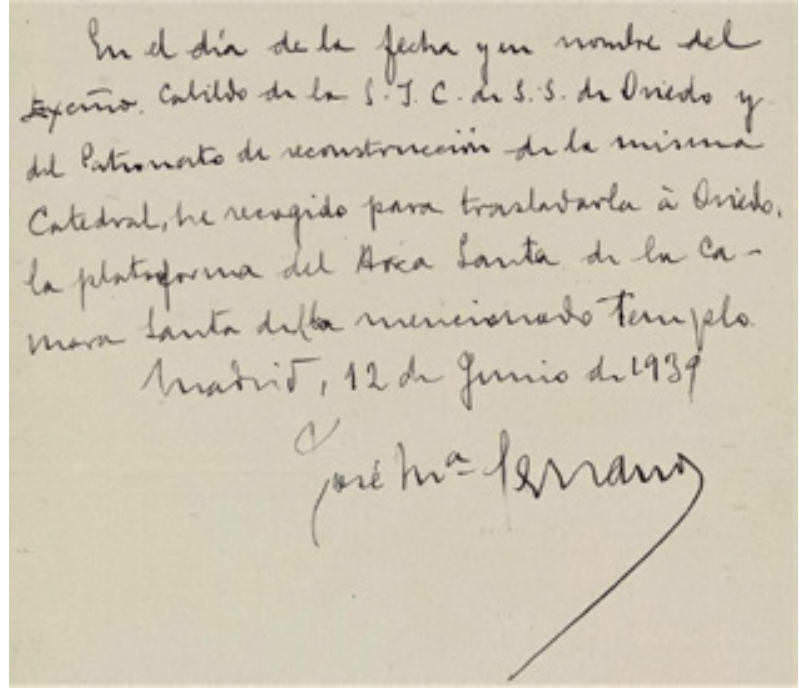

Fig. 8: Documento de recogida del Arca Santa en el Museo del Prado, 12.5.1935. Archivo Museo Nacional del Prado, Caja 93, Legajo 1524, Exp. 01, doc.02, f. 3

60 CUENCA BUSTO, C. Y HEVIA BIANCO, J: uLos promotores: episcopologio ovetense", en La Catedral de Oviedo. II. Catálogo y bienes muebles. Oviedo, Ediciones Nobel, 1999, vol. 2, p. 349.

61 Véase en la planimetría de Jorge Hevia y Cosme Cuenca, 1999. Este cuarto, anejo al espacio principa de la Sacristía General barroca, se ha relacionado siempre con la función de guardar las otras piezas de valor que no se encontraban en la Cámara Santa, entonces en ruinas. Otro lugar posible para su custodia pudo ser la Sacristía Alta.

62 Allíse presentó en algunas ceremonias en ese mismo mes de junio de 1939. Véase en fotografía junto la Cruz de la Victoria en el presbiterio de la referida capilla. Región, Oviedo, 24 de junio de 1939. Días antes, el 13 de junio se anunciaba para una celebración religiosa que tendría lugar cuatro días más tarde, que en dicho lugar se colocarían además del Arca Santa, las dos cruces y la Arqueta de Santa Eulalia. Región, Oviedo, 13 de junio de 1939 


\section{EL PRÉSTAMO A OTRAS EXPOSICIONES}

En septiembre de 1942 se colocó el Arca Santa en el lugar al que pertenecía tras casi ocho años de ausencia y adecuada a una nueva presentación del tesoro catedralicio ${ }^{63}$. Casi veinte años más tarde, una parte de las joyas de la catedral fueron exhibidas en los modernos locales de la Obra Social y Cultural de la Caja de Ahorros en septiembre de $1961^{64}$. Asimismo, en el verano de 1993, el Arca formó parte de la exposición Orígenes. Arte y Cultura en Asturias. Siglos VII-XV, a cargo de los profesores Javier Fernández Conde y María Cruz Morales Saro. La muestra incluyó una reformulación del relicario de la Cámara Santa. Allí, bajo un novedoso sistema de exposición que afectó al espacio, se exhibieron las cruces de los Ángeles y la Victoria, además de la Caja de las Ágatas y el Arca Santa ${ }^{65}$.

La pieza, dada su importancia, fue requerida para formar parte de la exposición Maravillas de la España Medieval. Tesoro Sagrado y Monarquía que tuvo lugar en la Real Colegiata de San Isidoro de León bajo el comisariado del profesor Isidoro Bango Torviso entre el 18 de diciembre de 2000 y el 28 de febrero de 2001. Sin embargo, su delicado estado de conservación en esa fecha, impidió un préstamo con garantías.

Por último, muy recientemente culminó un complejo proceso de intervención en la pieza con el ánimo de garantizar su conservación futura que vino acompañada de un minucioso estudio a cargo de los técnicos del Instituto del Patrimonio Cultural de España ${ }^{66}$.

63 MADRID ÁLVAREZ, V. de la: La Catedral de Oviedo. I. Historia y restauración, op. cit., p. 274 Una amplia crónica, acompañada de un reportaje gráfico se pueden consultar en CUESTA FERNÁNDEZ, J.: Crónica del Milenario de la Cámara Santa. MCMXLII. Oviedo, Ayuntamiento de Oviedo, 1947.

64 Véase cat. mano exp. XII Centenario de la Fundación de Oviedo. Exposición del Tesoro Artístico de la S I. Catedral de Oviedo. Oviedo, Galería de Exposiciones de la Caja de Ahorros de Asturias, del 11 al 30 de septiembre de 1961. También se preparó una cuidada y lujosa edición artística.

65 Esta muestra temporal sí aparece recogida en la amplia ficha catalográfica redactada por García de Castro en el marco del catálogo de bienes de la Catedral de Oviedo. Véase GARCÍA DE CASTRO VALDÉS, C.: «28. Arca Santa. 1075-1109» en La Catedral de Oviedo. II. Catálogo y bienes muebles. Oviedo, op. cit., pp. 43-46. El cerramiento y ambientación de la Cámara Santa para esta exposición temporal fue proyectado por Ignacio San Marcos Espinosa y Miguel Capellá Blanco. Véase cat. exp. $10^{\circ}$ Premios As turios de Arquitectura 1992-1993. Oviedo Colegio Oficial de Arquitectos de Asturias, 1994, pp. 76-77. turias de Arquitectu C. (Com.): Orígenes. Arte y Cultura en Asturias. Siglos VII-XV, op. cit., pp. 248-251.

66 La restauración tuvo lugar entre los meses de marzo y julio de 2017. Véase GARCÍA DE CASTRO VALDÉS, C.: El Arca Santa de la Catedral de Oviedo, op. cit., p. 9

\section{CONCLUSIONES}

El Arca Santa durante sus más de novecientos años de historia llegó en su prácticamente completa integridad al siglo XX, en que, tras participar en la Exposición Internacional de Barcelona, junto a lo más selecto del patrimonio medieval español, sufrió gravísimos daños en el marco de la Revolución de Octubre asturiana del año 1934, que también destruyó la Universidad Literaria de Oviedo y su renombrada biblioteca. A esta tragedia siguió un largo proceso de recuperación y de exilio de la pieza, que pasó por diversos enclaves de Madrid (Instituto Valencia de Don Juan, Museo Arqueológico Nacional, Museo del Prado e Iglesia de Santa Bárbara) para finalmente regresar casi cinco años más tarde al lugar para el que fue concebida, la Cámara Santa.

En su conservación y recuperación desempeñaron un papel fundamental aparte de Manuel Gómez-Moreno y su equipo de colaboradores, la Junta de Incautación del Tesoro Artístico Nacional y una comisión encabezada por José Cuesta y José María Serrano, quien en calidad también de secretario de la Asociación de Amigos y Antiguos Alumnos de la Universidad de Oviedo, propició que el Arca Santa se exhibiese en el Museo del Prado para así contribuir a la recaudación de fondos destinados a la extinta biblioteca ovetense. El Arca se pudo recuperar y la biblioteca también logró refundarse gracias a la compra en Madrid de la librería de Roque Pidal (1935), si bien en este último caso jamás se podrán reponer los libros y papeles reunidos desde el siglo XVIII por tantas generaciones de profesores y colaboradores.

El relicario ovetense ha sido sometido recientemente a una profunda restauración a cargo del IPCE que vino acompañada de estudios científicos de gran calado. Sin embargo, sigue pasando desapercibido todo lo concerniente al recorrido expositivo de la pieza que es también una parte más de su historia, pese a estar discretamente recogido en la historiografía disponible. Así, el Arca Santa fue seleccionada para su exhibición en Barcelona (1929), Madrid (1935) y Oviedo (1961 y 1993), siendo la del Museo del Prado la más emotiva de estas presentaciones, dado que significó la prueba inequívoca de su recuperación apenas medio año después de las dramáticas circunstancias referidas, lo que constatamos ahora en base a documentos, muchos inéditos. También referimos sus largos y oscuros años en almacenes de diferentes instituciones (Instituto Valencia de Don Juan, Museo Arqueológico Nacional y Museo Nacional del Prado) en fechas inmediatamente anteriores a la guerra civil y durante la misma, así como el uso de la pieza en ceremonias propagandísticas de la dictadura franquista (1939 y 1942), antes de ser devuelta al lugar del que forma parte insustituible. 


\section{BIBLIOGRAFÍA}

ALMAGRO GORBEA, Ma. J.: Catálogo del Arte Medieval Cristiano. Madrid, Museo Nacional de Reproducciones Artísticas, 1998.

ALONSO ÁLVAREZ, R.: «Patria uallata asperitate moncium»: Pelayo de Oviedo, el "archa" de las reliquias y la creación de una topografía regia», Locus Amoenus, nº 9, 2007-2008, pp. $17-29$

ARGERICH, I. y ARA, J.: Arte protegido. Memoria de la Junta del Tesoro Artístico durante la Guerra Civil. Madrid, Instituto del Patrimonio Cultural de España y Museo Nacional del Prado, 2009.

BANGO TORVISO, I. (Com.): Maravillas de la España Medieval. Tesoro Sagrado y Monarquía. León, 2000-2001 [cat. exp.].

BARÓN, J.; GARCÍA DE CASTRO VALDÉS, C.; GONZÁLEZ SANTOS, J.; HEVIA BA LLINA, A.; KAWAMURA KAWAMURA, Y.; MADRID ÁLVAREZ, V. de la; PLATERO FERNÁNDEZ-CANDAOSA, R.; SANHUESA FONSECA, Ma: Museo de la Iglesia Oviedo Catálogo de sus Colecciones. Oviedo, Museo de la Iglesia, 2009.

CASO, F. de; CUENCA BUSTO, C.; GARCÍA DE CASTRO VALDÉS, C.; HEVIA BLAN CO, J.; MADRID ÁlVAREZ, V. de la; RAMALLO ASENSIO, G..: La Catedral de Oviedo. Oviedo, Ediciones Nobel, 1999, 2 vols.

COLEGIO OFICIAL DE ARQUITECTOS DE ASTURIAS: $10^{\circ}$ Premios Asturias de Arquitectura. 1992-1993. Oviedo, Colegio Oficial de Arquitectos de Asturias, 1994 [cat. exp.].

CORONAS GONZÁLEZ, J.R.: Las Asociaciones de Antiguos Alumnos y Amigos de la Universidad de Oviedo de 1906 y 1934. Oviedo, Asociación de Antiguos Alumnos y Amigos de la Universidad de Oviedo, 2007.

CUESTA FERNÁNDEZ, J. y ARIAS DEL VALLE, R.: Guía de la Catedral de Oviedo. Oviedo, Asociación de Amigos de la Catedral de Oviedo, 1995.

CUESTA FERNÁNDEZ, J.: Crónica del Milenario de la Cámara Santa. MCMXLII. Oviedo, Ayuntamiento de Oviedo, 1947.
FERNÁNDEZ CONDE, J. y MORALES SARO, Ma C. (Com.): Orígenes. Arte y Cultura en Asturias. Siglos VII-XV. Oviedo, Lunwerg, 1993 [cat. exp.].

FERNÁNDEZ CONDE, F. J. y ALONSO ÁLVAREZ, R. (eds.): «Las reliquias de la catedra de Oviedo: Panorama general desde una perspectiva crítica (I)», Territorio Sociedad y Poder, $\mathrm{n}^{\circ} 11,2017$

FERNÁNDEZ CONDE, F. J. y ALONSO ÁLVAREZ, R. (eds.): «Las reliquias de la catedral de Oviedo: Panorama general desde una perspectiva crítica (II)», Territorio Sociedad y Poder, no $12,2018$.

GARCÍA CUETOS, Ma P., «La restauración del Prerrománico Asturiano: Luis Menéndez Pidal» y «La restauración del Prerrománico Asturiano en la primera mitad del siglo XX», en HEVIA BLANCO, J. (Coord.): La intervención en la arquitectura prerrománica asturiana. Oviedo, Universidad de Oviedo, 1997, pp. 97-118 y 119-136.

GARCÍA CUETOS, Ma P.: El Prerrománico Asturiano. Historia de la arquitectura y Restauración (1844-1976). Oviedo, Sueve, 1999.

GARCÍA CUETOS, $\mathrm{M}^{\mathrm{a}} \mathrm{P}$ : «La renovación de la Historia de la Arquitectura y del Arte en las primeras décadas del siglo XX: Manuel Gómez-Moreno», en BIEL IBÁÑEZ, Ma P. y HERNÁNDEZ MARTÍNEZ, A. (Coords.): Lecciones de los maestros: aproximación histórico-crítica a los grandes historiadores de la arquitectura española. Zaragoza, Instituto Fernando el Católico, 2011, pp. 125-158.

GARCÍA DE CASTRO VALDÉS, C.: El Arca Santa de la Catedral de Oviedo. Aguilar de Campoo, Fundación Santa María la Real del Patrimonio Histórico, 2017.

GARCÍA DE CASTRO VALDÉS, C.: «Datos y observaciones sobre el Arca Santa de la Cámara Santa de la catedral de Oviedo», Nailos. Estudios interdisciplinares de Arqueología, no 3, 2016, pp. 121-163.

GÓMEZ-MORENO, M. (Dir.): Exposición Internacional de Barcelona: El Arte en España. Guía del Museo del Palacio Nacional. Barcelona, Imprenta de Eugenio Subirana, 1929 [cat. exp.].

GÓMEZ-MORENO, M.: «El Arca Santa de Oviedo documentada», Archivo Español de Arte, no 69, 1945, p. 125-138. 
HEVIA GRANDA, V. y FERNÁNDEZ BUELTA, J. Ma: «La Cámara Santa de Oviedo. Su primitiva construcción, su reconstrucción y su reconstrucción», Boletín del Instituto de Estudios Asturianos, nº 6, 1949, pp. 51-116.

HEVIA OJANGUREN, P.: «Víctor Hevia: El estudio y los talleres del artista. Claustro de San Vicente-Cámara Santa-Sala Capitular», en LLORDÉN MIÑAMBRES, M. y MENÉNDEZ LLANA, J.M. (Eds.), I Congreso de Estudios Asturianos, vol. V, 2007, Oviedo, Real Instituto de Estudios Asturianos, pp. 177-1999.

LLANO AMPUDIA, A. de: Pequeños Anales de 15 días. La Revolución en Asturias. Octubre 1934. Oviedo, 1935.

MORALES, A. de: Viage de Ambrosio de Morales por orden del rey Phelipe II a los reynos de León, y Galicia, y Principado de Asturias. Madrid, Antonio Martín ed., 1765.

NAVARRO PÉREZ, Ma P. (Coord.), El Arca Santa de Oviedo. Investigación, documentación y restauración. Madrid, Ministerio de Cultura y Deporte, 2019.

RODRÍGUEZ ÁLVAREZ, R.: «La revolución de 1934 y sus consecuencias en la Universidad de Oviedo», Boletín de la Fundación Emilio Barbón, n 3, 2019, pp. 47-61.

TOLIVAR FAES, J.: Nombres y cosas de las calles de Oviedo. Oviedo, Ayuntamiento de Oviedo, 1992. 